\title{
Study of Cypermethrin Cytogenesis effects on Human Lymphocytes Using In-Vitro Techniques
}

\author{
${ }^{1}$ KALYAN CHAKRAVARTHI, B, ${ }^{1}$ RAMBABU NARAVANENI, ${ }^{* 2}$ PHILIP, G H \\ ${ }^{1}$ Research Scholar, Dept of Biotechnology, Sri Krishnadevaraya University, Anantapur-515001, Andhra Pradesh, India. \\ Email: kalyan_einstein@hotmail.com Tel: +91-9393710738, \\ ${ }^{1}$ Research Scholar, Genetics Department, Bhagawan Mahavir Medical Research Centre, A.C.Guards, Hyderabad-500 004, Andhra \\ Pradesh, India. Email: naravaneni@yahoo.com \\ ${ }^{2}$ Department of Zoology, Sri Krishnadevaraya University, Anantapur-515001, Andhra Pradesh, India \\ Email: philip_skuniv@yahoo.co.in Tel:+91-08554-255729.
}

\begin{abstract}
The Cytogenetic effects of Cypermethrin a synthetic pyrithroid insecticide was investigated on human lymphocytes cultured in-vitro. Utilizing the trypan blue dye exclusion technique assay the LC50 of cypermethrin was found to be $36 \mathrm{uM}$. Based on LC50 value, cypermethrin was found to be low toxic to lymphocyte culture. Cypermethrin showed an increase in the frequency of chromosomal aberrations and found to be significant. Karyotype analysis revealed more satellite associations and chromosomal breaks in cypermethrin treated samples. Low-doses of the pesticide also induced singlestrand breaks in the DNA as assessed by comet assay. The pesticide caused increase in the comet tail length with increase in pesticide concentration, implicating genotoxicity in somatic cells. It is concluded that In vitro assays could give important information of the mechanism of toxicity at low dosages and impact on genetic material of human origin. @JASEM
\end{abstract}

Pyrethriods are synthetic analogues of pyrethrins, the active substances in the flowers of Chrysanthemum, Cineraria folium. Pyrethroids can be classified into two large groups. Type I pyrethroids do not contain a cyano group in their molecules and include allethrin, tetramethrin, permethrin, and phenothrin. Type II pyrethroids contain a cyano group at the _ carbon position and include newer compounds, such as deltamethrin, cyphenothrin, cypermethrin, and fenvalerate. The two types of pyrethroids cause somewhat different symptoms of mammalian poisoning. Poisoning with type I pyrethroids is characterized by hyper excitation, ataxia, convulsions, and eventual paralysis; poisoning with type II pyrethroids, by hypersensitivity, choreoathetosis, tremors, and paralysis. Despite differences in the symptoms, both types of pyrethroids have the same major target site; the sodium channel of nerve membrane, i.e., the channel directly responsible for generating action potentials (Biologic basis of Neuro toxicity., 1992).

Cypermethrin has become one of the most important insecticides in wide scale use. It has wide uses in cotton, cereals, vegetables and fruit, for food storage, in public health and in animal husbandry. Cypermethrin, an analogue of pyrethrins is classified by the World Health Organization (WHO) as moderately hazardous (class II). It interacts with the sodium channels in nerve cells through which sodium enters the cell in order to transmit a nerve signal. These channels can remain open for up to seconds compared to the normal period of a few milliseconds, after a signal has been transmitted (Clark et al., 1989). Cypermethrin also interferes with other receptors in the nervous system. The effect is that of long lasting trains of repetitive impulses in sense organ (Abbassy et al., 1983).

Since cypermethrin is highly toxic to fish and bees, humans are indirectly affected as humans consume fish in their food and also honey which is made by the bees. Thus humans can be exposed to cypermethrin toxicity directly through spraying or contact methods or indirectly through consuming the pesticide-contaminated products like fish and honey. Hence there is a need for evaluating the toxicity at low doses, which can be studied easily using in vitro methods. The aim of the present investigation is to evaluate the cyto and genotoxicity of cypermethrin at low doses. The In vitro model system has been used instead of the animal model studies. The oral LD50 for cypermethrin in rats is $250 \mathrm{mg} / \mathrm{kg}$ (in corn oil) or $4,123 \mathrm{mg} / \mathrm{kg}$ (in water) (Meister., 1992). There is little human evidence that pyrethrins or pyrethroids cause health problems due to exposures. However, several animal studies have given us reasons for concern, specially the widespread use of these chemicals. 
The aim of the present study was to evaluate the effects of cypermethrin at cyto toxic and genotoxic levels in-vitro in peripheral blood samples of healthy human volunteers. The invitro model system as described by "Rambabu et al (2005), has been used in this investigation, and the main aim was to identify biomarkers of pesticide toxicity.

\section{METHODS AND MATERIALS}

The Pyrethroid pesticide used in this study was cypermethrin having the following structure:

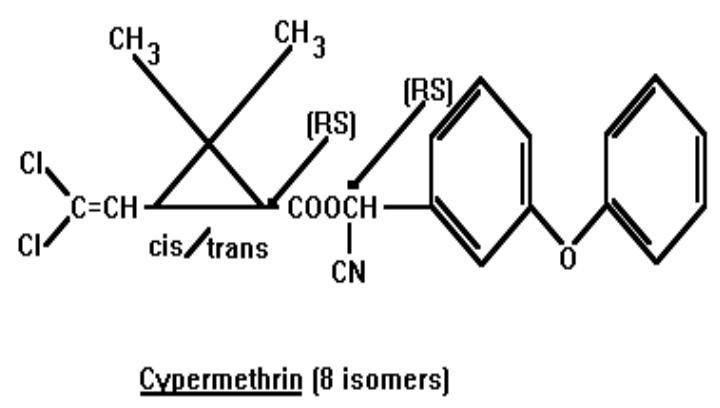

Molecular formula: $\mathrm{C}_{22} \mathrm{H}_{19} \mathrm{Cl}_{2} \mathrm{NO}_{3}$ Molecular weight: 416.32

IUPAC: (RS)-ý-cyano-3-phenoxybenzyl (1RS)cis,trans-3-(2,2-dichlorovinyl)-2,2dimethylcyclopropanecarboxylate

Stock solution (1\%) of cypermethrin pesticide was prepared in DMSO and various aliquots from the stock solutions were used through out the experiments. All experiments were carried out in triplicates and averages recorded. Preparations of reagents and solutions were carried out as per the standard procedures described by the relevant authors (Cremlyn., 1978.).

Fresh blood from healthy non-smoking individuals was collected in heparinized syringes and transferred in the eppendorf tubes and used immediately for the determination of cytotoxicity, chromosomal aberrations and DNA damage.

Short-term lymphocyte culture using the whole blood samples was set up following the methods described earlier by "Kaiser Jamil et al., (2004)". Simplest method of lymphocyte culture is incubation of a small amount of whole blood without previous separation of erythrocytes and granulocytes. This utilizes all available lymphocytes, which are usually $25-50 \%$ of the leukocyte count i.e. 1,800-5,000 cells per $\mathrm{mm}^{3}$ of blood.
The in-vitro cytotoxic effect of the cypermethrin pesticide was estimated by the Trypan blue dye exclusion technique. Trypan blue penetrates dead cells through damaged membrane, staining the nucleus. Cells were counted using a Neubauer's chamber (Haemocytometer) and the number of viable (opaque) and dead cells were scored by direct observation under the bright field microscope.

The cytotoxicity of cypermethrin was determined at various concentrations against lymphocytes killed. The log concentrations and percent kill data obtained as above were subjected to probit analysis by using "the probit model program of "Reddy et al (1992)", and lethal concentration ${ }_{50}\left(\mathrm{LC}_{50}\right)$ for test compound was calculated. The protocol for chromosomal aberration analysis was essentially as described earlier (Moorhead et al., 1960). Chromosome preparations were screened after adding colchicine to arrest the cells in metaphase stage (after $72 \mathrm{hrs}$ of initiation of cultures). These were fixed in methanol and acetic acid (3:1) and plates were flame dried and stained with $4 \%$ giemsa before viewing under microscope and recording the images in the Mediimage software program.

Experiments were carried out to standardize the procedures to detect chromosomal aberrations with proper controls. Normal and treated blood samples were processed as described above and well-spread metaphase plates were analysed for the chromosome aberration frequency. Attempt was made to screen at least 100 cells per each concentration every time. Initiation for the culturing of lymphocytes was done in duplicates under sterile conditions. 2 units of PHA or Lectin were added to each media vial (Kolodny and Hirschhorn., 1964 ; Coulson and Chalmers., 1964). Then $15 \mu \mathrm{l}$ of freshly collected whole blood was added to each vial and the vials were kept for incubation at $37^{\circ} \mathrm{C}$ for $72 \mathrm{hrs}$. At the end of $48 \mathrm{th} \mathrm{hr}$ of incubation, various concentrations of cypermethrin pesticide solution was added to the tubes and incubated further for another 24hrs (IAEA., 1983). The tubes were shaken every morning until processed. The experiments were carried out using various aliquots from the stock solution of the cypermethrin. The concentrations used for the chromosomal aberration experiment were sub-lethal or low doses of the $\mathrm{LD}_{50}$ in varying concentrations. The lymphocytes were incubated with the cypermethrin pesticide for 24 hours.

The DNA damage studies were carried out using comet assay, i.e. Single Cell Gel Electrophoresis (SCGE). Single Cell Gel Electrophoresis (SCGE), commonly known as comet assay was carried out as 
per the procedure described by "Singh et al (1988)" with slight modifications as described below. Pre cleaned slides were layered with $140 \mu$ of $1 \%$ regular agarose to promote even and firm attachment of subsequent layers. Second layer includes $110 \mu$ l of $0.5 \%$ low melting agarose along with the $20 \mu \mathrm{l}$ of sample material (i.e. cypermethrin treated blood). The final layer comprised of $110 \mu \mathrm{l}$ of low melting agarose alone. After solidification of agarose, the slides were immersed in cold lysing solution $(2.5 \mathrm{M}$ $\mathrm{NaCl}, 100 \mathrm{mM} \mathrm{Na}_{2}$ EDTA and $300 \mathrm{mM} \mathrm{NaoH}, 1 \%$ sodium sarcocinate, $\mathrm{pH}$ adjusted to $10,10 \%$ DMSO and $1 \%$ Triton $\mathrm{X} 100$ added fresh) and stored overnight at $4^{\circ} \mathrm{C}$. The slides were removed from lysing solution and were placed on a horizontal gel electrophoretic unit. The unit was filled with freshly made alkaline buffer $\left(1 \mathrm{mM} \mathrm{Na}_{2}\right.$ EDTA and $300 \mathrm{mM}$ $\mathrm{NaoH}, \mathrm{pH}>13$ ). The slides remained submerged in the buffer for $20 \mathrm{~min}$. Electrophoresis was carried out in the same buffer for $25 \mathrm{~min}$ at $25 \mathrm{v}$ and $30 \mathrm{~mA}$. DNA fragments in each cell migrate at a rate inversely proportional to the size of the fragments. Slides were then washed gently 2-3 times, at intervals of $5 \mathrm{~min}$ each with $0.4 \mathrm{M}$ Tris at $\mathrm{pH} 7.5$ (neutral buffer). After final wash the neutral buffer was drained and each slide was stained with $60 \mathrm{ml}$ of silver nitrate covered with a micro glass coverslips and sealed. The slides were viewed under a microscope, which has a CCD camera attachment and connected to a computer with Medi-Image software containing frame grabber, viewer, and saving in a library and finally printable version was obtained. The LD50 value of the cypermethrin obtained from the Trypan blue viability test is $36 \mu \mathrm{M}$.

All experiments for chromosomal aberrations were carried out in triplicates, and for each set 100 metaphases were screened. The chromosomal aberration frequency was found to be dosedependent, with increasing gaps, breaks and sat associations as compared to untreated (control).

\section{RESULTS AND DISCUSSION}

The cytotoxic effects of the cypermethrin were determined by the loss of membrane integrity by trypan blue dye exclusion method. Our experiments indicated a clear dose dependent cytotoxic effect of the pesticide on lymphocytes. The percent viability of the cells decreased with increase in the concentration of the pesticide. The results are represented in Figure 1. From this data, the LD-50 values were calculated using probit analyses, and it was found that cypermethrin at a concentration of $36 \mathrm{mM}$ gave $50 \%$ mortality when incubated with lymphocytes as described earlier.

Chromosomal aberrations in the form of chromatid breaks, gaps and satellite associations were observed at sub lethal concentrations (i.e. 1/10 LC50). Results obtained from the chromosomal analysis data of metaphase plates are presented in the Table-I. It was found that the number of breaks, gaps and Satellite associations increased as the concentration of the pesticide increased.

Table I. Showing the frequency of chromosomal aberrations in untreated (control) and treated (cypermethrin) lymphocytes.

\begin{tabular}{|c|c|c|c|c|c|c|}
\hline $\begin{array}{l}\text { Cypenethrin } \\
\text { Comcertrations } \\
\text { in } \mu \mathrm{Ml} \text { (24 hrs) }\end{array}$ & $\begin{array}{l}\text { Himber df } \\
\text { metrphoses } \\
\text { sored }\end{array}$ & $\begin{array}{l}\text { Himber of } \\
\text { metrphases } \\
\text { writh treaks }\end{array}$ & $\begin{array}{l}\text { Himber of } \\
\text { metmphoses } \\
\text { will ges }\end{array}$ & $\begin{array}{c}\text { Himber of } \\
\text { mintophses } \\
\text { wth Satellite } \\
\text { associatians }\end{array}$ & $\begin{array}{c}\text { Himber of } \\
\text { metaphoses } \\
\text { wth inveupbide } \\
\text { cells }\end{array}$ & $\begin{array}{l}\text { Percent cells } \\
\text { will } \\
\text { aberrations }\end{array}$ \\
\hline Cantrol & 100 & F互 & F互 & F互 & F面 & 0 \\
\hline 36 & 100 & 陑 & F五 & 1 & Fin & 1 \\
\hline 46 & 100 & Fil & 2 & 3 & 1 & 6 \\
\hline 56 & 100 & 陑 & 6 & 4 & 3 & 13 \\
\hline 66 & 100 & 1 & 7 & 8 & 5 & 21 \\
\hline 76 & 100 & 3 & 10 & 12 & 7 & 32 \\
\hline
\end{tabular}

The DNA damaging effects induced by the cypermethrin has been studied in-vitro using Alkaline Single Cell Gel Electrophoresis (comet assay). The results of comet assay for various concentrations of the cypermethrin are tabulated in Table II. It is evident from these results that the comet tail length increased from $12.28 \mu \mathrm{m}$ to $44.00 \mu \mathrm{m}$ with the increase in the concentration of cypermethrin from $3.6 \mathrm{mM}$ to $7.6 \mathrm{mM}$. This is indicative of the single strand DNA breaks in these treatments.
In-vitro studies on human blood samples can give information of the toxicological effects of the cypermethrin in human blood samples. So far there are few reports of the impact of cypermethrin on lymphocyte cultures of humans (Amer., 1993). Lowdoses of the cypermethrin pesticide could induce single strand breaks in DNA. Animal model studies have also indicated that when administered to pregnant and nursing rats, cypermethrin may lead to genotoxicity and also neurotoxicity by functional delay in the brain maturation of the pups. The 
toxicity to young rats is higher, may be because the pathway for degrading cypermethrin is not fully developed in young rats (Cypermethrin Environmental health criteria., 1989). The present study on the frequency of chromosomal aberrations suggests that conditions like aneuploidy could occur in humans. However, these changes may induce certain disease conditions at the individual level, which may not be inherited by the progeny. It is also possible that these aberrations could be rectified by DNA repair mechanisms, indicating recovery from the diseased conditions.

Table II. Means+SD Comet tail length $(\mu \mathrm{m})$ in lymphocytes treated with cypermethrin pesticide.

\begin{tabular}{|c|c|c|}
\hline $\begin{array}{l}\text { Cypermethrin } \\
\text { Concentrations } \\
\text { in } \mu \mathrm{M}\end{array}$ & $\begin{array}{l}\text { No. Of cells } \\
\text { scored }\end{array}$ & $\begin{array}{l}\text { Average tail } \\
\text { length in } \mu \mathrm{m} \\
(\mathrm{mean} \pm \mathrm{SD})\end{array}$ \\
\hline Control & 100 & $1.155 \pm 0.754$ \\
\hline 3.6 & 100 & $12.28 \pm 1.154$ \\
\hline 4.6 & 100 & $16.71 \pm 1.052$ \\
\hline 5.6 & 100 & $25.97 \pm 1.131$ \\
\hline 6.6 & 100 & $32.58 \pm 1.155$ \\
\hline 7.6 & 100 & $44.00 \pm 1.788$ \\
\hline
\end{tabular}

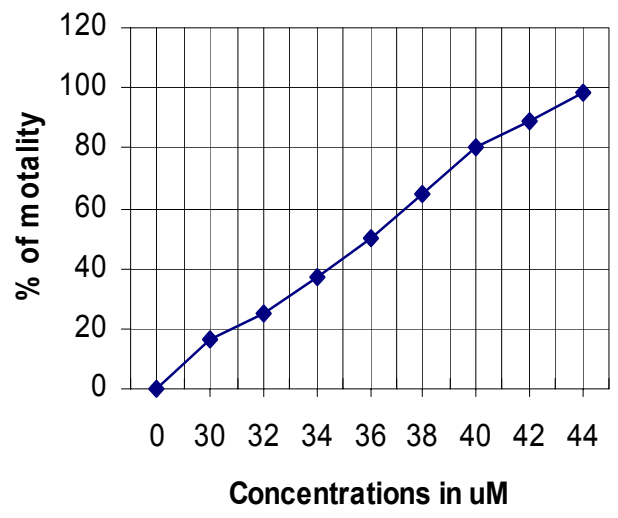

Fig 1. Concentration vs. mortality of cypermethrin pesticide

Comparative biochemical analysis on cypermethrin is not available except for one report on the occurrence of acceptable daily intake (ADI) in rodent juveniles (Ferah et al., 2005), which has not been confirmed so far. The relatively rapid degradation of cypermethrin means that it is not generally found as residue in food. The present investigations on using In vitro assays are, however, seems to be very useful shortterm assays, which could be used for a wide number of chemicals for quick screening methods directly related to human toxicology. Medical diagnosis of cypermethrin toxicity indicates that mild poisoning is short-lasting and in case of occupational overexposure medical intervention are essential
(Ellenhorn and Barceloux., 1988). It is reported that $5 \%$ sodium bicarbonate lavage can be used if the patient has ingested the pesticide. In severe cases, the medical practice includes phenobarbital or diphenylhydantion or their mixture may be given (Ghousia ., 2005). Cypermethrin has been reported to be highly toxic to aquatic organisms and fish as well as to bees (Davis., 1993; Sarkar at al., 2005). Hence, awareness serves as a vital role for pesticide users in order to overcome the hazards caused by the xenobiotics in gener

Acknowledgement: Rambabu Naravaneni and B. Kalyan Chakravarthi are thankful for the facilities provided by Sri Krishnadevaraya University for this Research Activity to be carried out in this University.

\section{REFERENCE}

Abbassy, M A; Eldefrawi, M E \& Eldefrawi, A T (1983). Pyrethroid action on the nicotinic acetylcholine receptor / channel, Pesticide Biochem Physio, 19: 299.

Amer, S M (1993). Induction of chromosomal aberrations and sister chromatid exchange in vivo and in vitro by the insecticide cypermethrin. $\mathrm{J}$ Appl Tox, 13: 341.

Biologic basis of Neuro toxicity (1992). Env Neu Tox, National Academies Press, 21.

Clark J M ; Brooks M W (1989). Neurotoxicology of pyrethroids: single or multiple mechanisms of action?, Environ Toxicol Chem, 8: 361.

Coulson, A S ; Chalmers, D G (1964). Effects of phytohaemaglutinin on leucocytes. Lancet. II. 819.

Cremlyn, R (1978). Pesticides Preparation and mode of action in herbicides R.Cremlyned, John Wiley and sons Ltd. Chickester. 140-172.

Cypermethrin Environmental health criteria 82 (1989). WHO, Geneva

Davis B N K (1993). Insecticide drift from groundbased, hydraulic spraying of peas and Brussels sprouts â€" bioassays for determining buffer zones, Agricult. Ecosyst. Environm, 43: 93.

Ellenhorn M J ; Barceloux D G (1988). Medical toxicology - Diagnosis and treatment of human poisoning, (Elsevier Science Publishing Co Inc), New York, 1077. 
Ferah, Sayum ; Netise, Ulku ; Kerabay, Yavasoglu; Yigit, Uyamkgil ; Huseyin, Aktug ; Altug, Yavasoglu ; Mehmet, Turgut (2005). Neurotoxic effects of cypermethrin in wistar rats: a Haematological, Biochemical and Histopathological study, J Health Sci, 51: 300.

Ghousia, Begum (2005). Toxicity of cypermethrin on total lipids and free fatty acids in liver, muscle, kidney and ovary of Clarias batrachus (L) and recovery response, Toxicol Environment Chem, 87: 253

IARC (1983). Miscellaneous pesticides. Lyons, International Agency for Research on Cancer. IARC Monographs on the Evaluation of Carcinogenic Risk of Chemicals to Man, Vol. 30: Appendix 359-406.

Kaiser, Jamil ; Abjal Pasha, Shaik ; Mahboob, M; Krishana, D (2004). Effect of organophosphorus and organochlorine pesticides (Monocrotophos, Chlorpyriphos, Dimethoate and Endosulfan) on human lymphocytes in-vitro. Drugs and Chemical Toxicology. 27 (2) 133-144.

Kolodny, R L ; Hirschhorn, K (1964). Properties of phytohaemagglutinin. Nature (Lond) 201: 715.
Meister, R T (1992). Farm Chemicals Handbook, Meister Publishing Company. Willoughby, $\mathrm{OH}$.

Morrhead, P S ; Nowell, P C ; Mellman, W T ; Baffips, D.M ; Hungerford, D A (1960). Chromosome preparations of leukocytes cultured from human peripheral blood. Exptt. Cell. Res. 20: 613-616.

Rambabu Naravaneni ; Kaiser Jamil (2005). Cytogenetic Biomarkers of Carbofuran toxicity using human lymphcyte culture in-vitro. Drug and Chemical Toxicology, 28: 359-372.

Reddy, P J ; Krishna, D ; Suryanarayana Murthy, U ; Kaiser, Jamil (1992). A microcomputer FORTRAN program for rapid determination of lethal concentrations of biocides in mosquito control. CABIOS. 8, 3, 209-213.

Sarkar, B ; Chatterjee, A ; Adhikari, S ; Ayyappan, S (2005). Carbofuran and cypermethrin- induced histopathological alterations in the liver of Labeo rohita (Hamilton) and its recovery, App Ichthyol, 21: 131 .

Singh, N P ; McCoy, M T ; Tice, R R ; Schneider, E L (1988). A simple technique for quantitation of low level of DNA damage in individual cells. Exp Cell. Res. 175:184-191. 